\title{
INFLUENCE OF ANTERIOR LOAD AND RESTORATIVE PROCEDURE ON MAXILLARY INCISORS WITH DIFFERENT CERVICAL WEAR MORPHOLOGIES
}

\author{
INFLUENNCIA DO PROCEDIMENTO RESTAURADOR E DE CONTATO ANTERIOR \\ EM INCISIVOS SUPERIORES COM DIFERENTES MORFOLOGIAS DE DESGASTE \\ CERVICAL
}

\author{
Alexandre Coelho MACHADO ${ }^{1}$; Lívia Fávaro ZEOLA $^{2}$; Marina Ferreira de Lima NAVES ${ }^{2}$; \\ Vitor Laguardia Guido FARIA ${ }^{2}$; Igor Oliveiros CARDOSO ${ }^{2}$; Paulo Vinícius SOARES ${ }^{3}$ \\ 1. NCCLs Research Group, Technical Health School, Federal University of Uberlandia, Uberlandia, MG, Brazil; 2. NCCLs Research \\ Group, School of Dentistry, Federal University of Uberlandia, Uberlandia, MG; 3. NCCLs Research Group Advisor, School of \\ dentistry, Federal University of Uberlandia, Brazil, Uberlandia, MG, Brazil. paulovsoares@ yahoo.com.br
}

\begin{abstract}
The aim of this study was to evaluate the influence of different anterior load type and restorative procedure on stress distribution of maxillary incisors with different noncarious cervical lesions (NCCLs) morphologies. Three-dimensional models of a maxillary incisor were generated. Beyond the sound model (SO), five NCCLs morphologies were simulated: shallow ( $\mathrm{SH}$ ), notched (NO), concave (CO), wedge-shaped (WS) and irregular with dual center (IR' and IR"). Composite resin restoration of all the models was simulated (R). Two different anterior loads were applied: $100 \mathrm{~N}$ on palatine middle third (ML) and $500 \mathrm{~N}$ on palatine incisal third (IL). The data were obtained in MPa using the Maximum Principal Stress and Von Mises criteria and the statistical analysis was performed (paired t-test with 95\% confidence level). The IL provided higher compressive stress than ML, mainly on WS (-136.3MPa), IR" (-117.5) and NO (-71.1 MPa). The highest tensile stress found within the restored models was on NOR with IL (19,1 MPa). The Von Mises results showed higher stress concentration on non-restored and IL models $(\mathrm{p}<0.001)$. The anterior load type and restorative status were determinant factors on stress distribution pattern changes, whereas NCCLs morphologies had little influence in maxillary incisors.
\end{abstract}

KEYWORDS: Anterior Load. Composite Resin Restoration. Finite Element Analyses. Maxillary Incisors. Noncarious Cervical Lesions.

\section{INTRODUCTION}

Noncarious cervical lesions (NCCLs) are multifactorial pathological wears originated by the loss of tooth structure in the cervical third of the crown, reaching the root surface, that is unrelated to dental caries (MICHAEL et al., 2009; PECIE et al., 2011). The occurrence of these lesions is an increasingly common finding in dental clinical practice with prevalence rates up to $85 \%$ in some populations (QUE et al., 2013). There are three main factors related to the origin and progression of the NCCLs: biocorrosion (chemical, biochemical and electrochemical degradation - caused by extrinsic and intrinsic acids), friction (wear and toothbrush/dentifrice abrasion), and stress (abfraction - caused by parafunction, traumatic occlusion and occlusal overload presence) (GRIPPO et al., 2012).

Among all factors involved in this process, the role of the stress has been much discussed in the literature (LEE; EAKLE, 1984; MICHAEL et al., 2009; GRIPPO et al., 2012; FRAGOSO et al., 2013; SOARES et al., 2015; ZEOLA et al., 2015). The term "abfraction" has been used for decades to describe the loss of tooth structure by overcoming bonds between hydroxyapatite crystals due to the stress concentration, distant from the area which the force was applied (LEE; EAKLE, 1984; GRIPPO et al., 2004; MICHAEL et al., 2009). Actually, occlusal interferences, parafunctional habits and bruxism change the magnitude, direction, frequency, duration and localization of the occlusal contacts, which result in different biomechanical behavior in these non-physiological situations (OMMERBORN et al., 2007; BRANDINI, PEDRINI, et al., 2012; BRANDINI, TREVISAN, et al., 2012; SOARES et al., 2015; ZEOLA et al., 2015). Then, these excessive loads generate dental tissues flexion which reaches the ultimate structure resistance and makes the structure more susceptible to other NCCLs etiological factors (LEE E EAKLE, 1984; MICHAEL et al., 2009).

Several studies have examined the characteristics of NCCLs, such as prevalence in the population (QUE et al., 2013); teeth most affected (BORCIC et al., 2004; QUE et al., 2013); and the extent of damage through subjective observations 
and also using scanning electron microscopy (MICHAEL et al., 2010; HUR et al., 2011; WALTER et al., 2014). Despite posterior teeth presents higher prevalence of NCCLs than anterior, this discrepancy is attenuated with age (LAI et al., 2015). Moreover, $48.2 \%$ and $57.1 \%$ of maxillary and mandibular anterior teeth, respectively exhibit NCCLs associated with cervical dentin hypersensitivity (QUE et al., 2013). In this way, the NCCLs in anterior teeth were catalogued and classified based on their morphological appearance in eight types: two shallow types, notched, concave, wedge-shaped and three irregular types (MICHAEL et al., 2010).

The multifactorial etiology of NCCL and these various anatomic aspects result in unclear treatment protocols that are still controversial (WOOD et al., 2008). Among these controversies, some studies do not consider possible to make the association between malocclusion and parafunctional habits with the presence of NCCLs (WOOD et al., 2009; SENNA et al., 2012; SILVA et al., 2013), and others authors support the protocol of removal sclerotic dentin, rounding the internal angle of the lesion and even not restore the NCCL cavity, which results in a confusing clinical management (WOOD et al., 2008; SOARES et al., 2015). These instructions combined with the need for esthetic improvement (MICHAEL et al., 2009), justified the importance of more specific knowledge related to the progression and management of NCCLs in anterior teeth.
Non-destructive methods, as finite element method, allow the simulation of dental structures and its biological proprieties, which can contribute for analysis of dental behavior and clinical management, as the influence of load types and restorative protocols (SOARES et al., 2015). Thus, the purpose of this study was to evaluate the stress distribution pattern on maxillary incisors with different NCCLs morphologies, according to their restorative status and load type, using threedimensional (3D) finite element analysis. The null hypothesis tested is that the load type, restorative procedure and NCCL morphologies would not change the biomechanical behavior of maxillary incisor.

\section{MATERIAL AND METHODS}

Three-dimensional linear and elastic finite element analysis was performed using geometric anatomical representations of the pulp, dentin, enamel, periodontal ligament, and cortical and medullar bones (SOARES et al., 2015). Six computer-aided design (CAD) models were generated (Rhinoceros 3D software, Rhinoceros, Miami, FL, USA) simulating sound tooth (SO) and five NCCL morphologies: shallow (SH), notched (NO), concave (CO), wedge-shaped (WS) irregular with dual center (IR' and IR") and also the restored models of all lesions types (R) (Figure 1). The characteristics of the simulated morphologies are described on Table 1(MICHAEL et al., 2010).

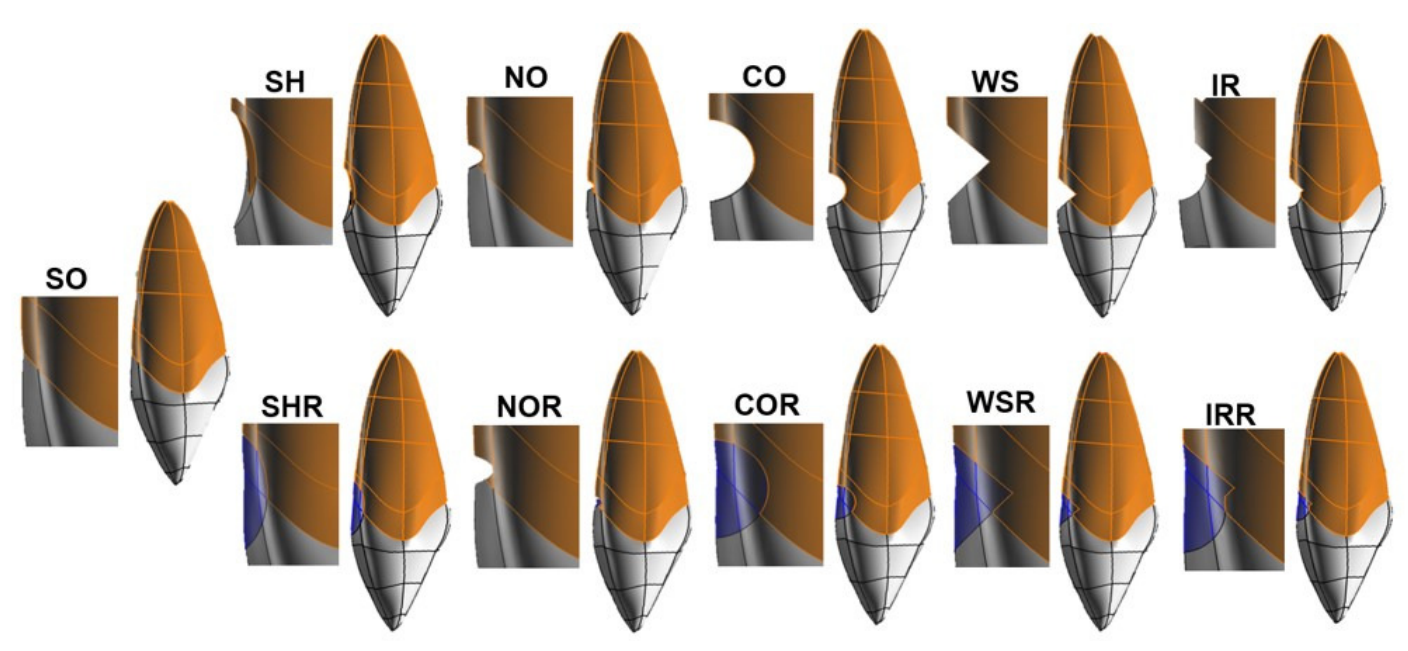

Figure 1. Anterior NCCLs morphologies and their respective restored models: SO-Sound Tooth; SH Shallow; NO - Notched; CO-Concave; WS- Wedge-Shaped; IR-irregular with dual center; Rrestored models of all lesions types. 
Table 1. Description of NCCL morphologies characteristics and their synonymous terms, present in parentheses ${ }^{15}$.

\begin{tabular}{|c|c|}
\hline NCCL MORPHOLOGIES & NCCL DESCRIPTIONS \\
\hline $\begin{array}{c}\text { Shallow } \\
\text { (dished-out, saucer-shaped) }\end{array}$ & $\begin{array}{l}\text { Displayed depth less than or equal to } 0.5 \mathrm{~mm} \text {, with } \\
\text { width and height dimensions greater than } 1.0 \mathrm{~mm} \text {; } \\
\text { - Minimal dentine exposure; } \\
\text { The cross-sections of shallow NCCLs are either flat } \\
\text { or curved. }\end{array}$ \\
\hline $\begin{array}{l}\text { Notched } \\
\text { (shallow grooves, grooved, } \\
\text { gingival notching, deep notches) }\end{array}$ & $\begin{array}{l}\text { - Displayed a very short corono-apical height }(0.5-1.0 \\
\mathrm{mm}) \text { relative to a longer mesio-distal length }(4.0-6.0 \\
\mathrm{mm}) ; \\
\text { - The cross-sections are either wedge-shaped or } \\
\text { concave; }\end{array}$ \\
\hline $\begin{array}{c}\text { Concave } \\
\text { (cupped, c-shaped) }\end{array}$ & $\begin{array}{l}\text { Displayed a concave cross-section present a depth } \\
\text { greater than } 0.5 \mathrm{~mm} \text {; } \\
\text { Did not demonstrate a well-defined internal line } \\
\text { angle; } \\
\text { - The walls of these lesions are continuously curved. }\end{array}$ \\
\hline $\begin{array}{l}\text { Wedge-shaped } \\
\text { (v-shaped) }\end{array}$ & $\begin{array}{l}\text { - Displayed a wedgeshaped cross-section; } \\
\text { flat internal floors. }\end{array}$ \\
\hline Irregular & $\begin{array}{l}\text { - They cannot be categorized into one of the above } \\
\text { NCCL categories; } \\
\text { - Displayed an irregular cross-section, with either } \\
\text { angular features, curved features or a combination of } \\
\text { angular and curved features. }\end{array}$ \\
\hline
\end{tabular}

The models were exported to the processing analysis software (ANSYS 12.0, Ansys Workbench 12.0, Canonsburg, PA, USA) using the Standard for the Exchange of Product Data (STEP) format. In this software, the following steps were performed: preprocessing (definition of mechanical properties, volumes, connection types, mesh for each structure, and boundary conditions), processing (data calculation), and post-processing (analysis of results by stress distribution criteria). Enamel and dentin were considered orthotropic and the other structures isotropic (Table 2) (CARTER e HAYES, 1977; WEINSTEIN et al., 1980; RUBIN et al., 1983; SHINYA et al., 2008; MIURA et al., 2009).

Table 2. Mechanical properties used to simulated orthotropic and isotropic structures.

\begin{tabular}{|c|c|c|c|}
\hline \multirow[t]{2}{*}{ Structures } & \multicolumn{3}{|c|}{ Orthotropic Structures ${ }^{22}$} \\
\hline & LONGITUDINAL & TRANSVERSAL & $\mathbf{Z}$ \\
\hline & \multicolumn{3}{|c|}{ Elastic Modulus (MPa) } \\
\hline Enamel & 73720 & 63270 & 63270 \\
\hline \multirow[t]{2}{*}{ Dentin } & 17070 & 5610 & 5610 \\
\hline & \multicolumn{3}{|c|}{ Shear coefficient (MPa) } \\
\hline Enamel & 20890 & 24070 & 20890 \\
\hline \multirow[t]{2}{*}{ Dentin } & 1700 & 6000 & 1700 \\
\hline & \multicolumn{3}{|c|}{ Poisson Ratio (v) } \\
\hline Enamel & 0.23 & 0.45 & 0.23 \\
\hline Dentin & 0.30 & 0.33 & 0.30 \\
\hline \multirow[t]{2}{*}{ Structures } & \multicolumn{3}{|c|}{ Isotropic Structures } \\
\hline & Elastic M & MPa) & Poisson Ratio (v) \\
\hline Pulp $^{25}$ & & & 0.45 \\
\hline Periodontal Ligament ${ }^{23}$ & & & 0.45 \\
\hline Cortical Bone ${ }^{24}$ & & & 0.30 \\
\hline Medular Bone $^{24}$ & & & 0.30 \\
\hline Hybrid Composite Resin ${ }^{26}$ & & & 0.27 \\
\hline
\end{tabular}


After testing the mesh conversion to define the appropriate refinement level, volumes corresponding to each structure were meshed with controlled and connected elements. The meshing process involved the division of the studied system into a set of small discrete elements defined by nodes. Solid quadratic tetrahedral elements of 10 nodes were used (Figure 2a). The mesh conversion test was initiated using the software automatic meshing tool and was continued by gradual reduction of the elements size. For each test stage, the results were generated by equivalent stress criterion (von Mises) to verify the highest stress values of dentin. The mesh was considered satisfactory when, even reducing the dimension of elements, the highest stress levels were similar to the results observed with the previous mesh refinement. The number of elements used varied depending on the different volumes, so that the final model accurately represented the original geometry.
Due to the adhesive properties of the restorative material used, restorations were bonded to dental structures by considering a mesh connection with dentin and enamel.

After the mesh step, boundary conditions were determined. Loads were applied in specific surfaces previously defined in the CAD software, as follows: $100 \mathrm{~N}$ on Palatine Middle Third Load (ML) (Fig. 2b) and $500 \mathrm{~N}$ on Palatine Incisal Third Load (IL) (Fig. 2c) (POIATE et al., 2009). The intensity and localization of ML represents the standard force during the masticatory function on a sound maxillary central incisor. On the other hand, the magnitude and area of IL represents a parafunctional habit and non-physiological contact (POIATE et al., 2009; FRAGOSO et al., 2013). Finally, the models were restrained at the base and lateral surfaces of cortical and medullar bones to avoid displacement (Fig. 2d).

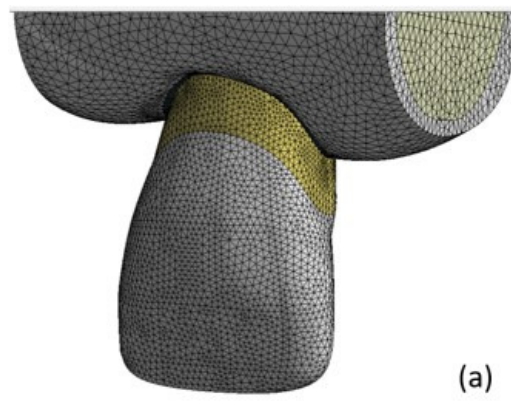

(a)

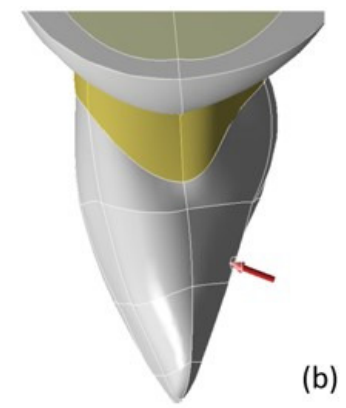

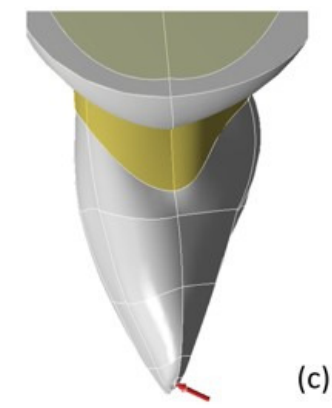

(c)

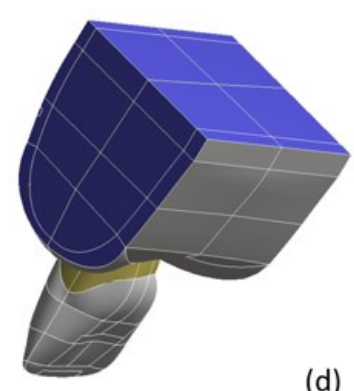

Figure 2. Pre-processing of finite element analysis. (a) Mesh with solid quadratic tetrahedral elements of 10 nodes. (b) Palatine Middle Third Load - 100N (ML). (c) Palatine Incisal Third Load - 500N (IL) and (d) Displacement restriction (null on blue area).

Stress distribution analysis was performed using Maximum Principal Stress and Von Mises criterion, measured in MPa. After complete stress analysis in all structures, the results were plotted in transparency, except for enamel and dentin, for better visualization, using Maximum Principal Stress. In addition, in the sagittal analysis, the composite resin restoration was plotted to identify the stress on the restorative material. For a specific analysis, the deepest node on the bottom of the lesion (BL) was selected to obtain the stress values, according to the lesion type. Since irregular is a dual center morphology, one node was selected for each bottom of the lesion (Figure 3). The effect of restorative procedure (Non-restored NCCL X Restored NCCL) and load type (Palatine Middle Third Load X Palatine Incisal Third Load) were analyzed by paired t-test with based on equivalent stress values (von Mises). All tests were performed at a 95\% confidence level, using the Sigma Plot 12.0 software. 

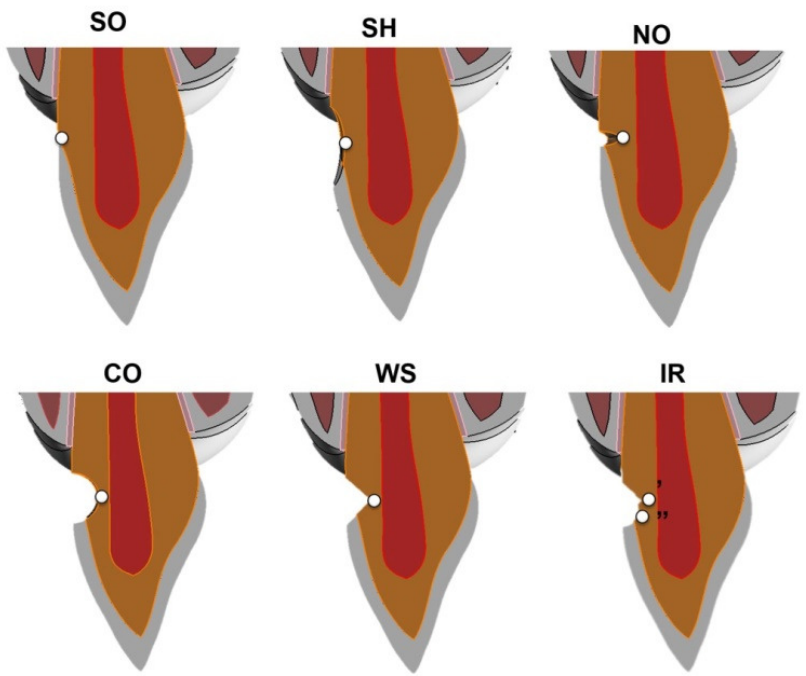

Figure 3. Specific analysis on the bottom of the lesion (BL) for each morphology, independently of the presence of composite restoration. The deeper node was selected to obtain the stress values (MPa).

\section{RESULTS}

The maximum principal stress distribution patterns of all models under different load types are represented in Figures 4, 5, 6 and 7. Positive and negative values indicate the regions which were subjected to tensile or compressive stresses, respectively.
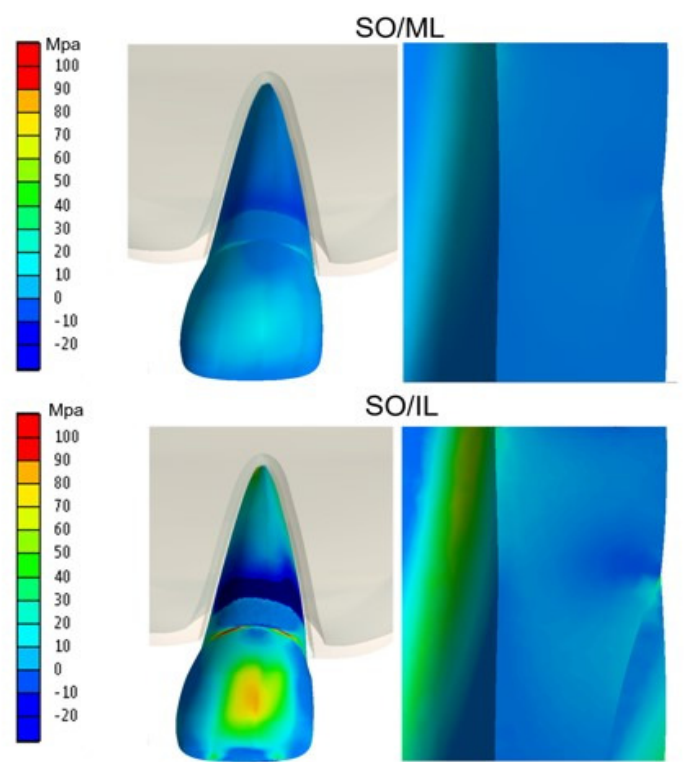

Figure 4. Maximum Principal Stress (MPa) distribution pattern for sound models submitted to ML and IL.
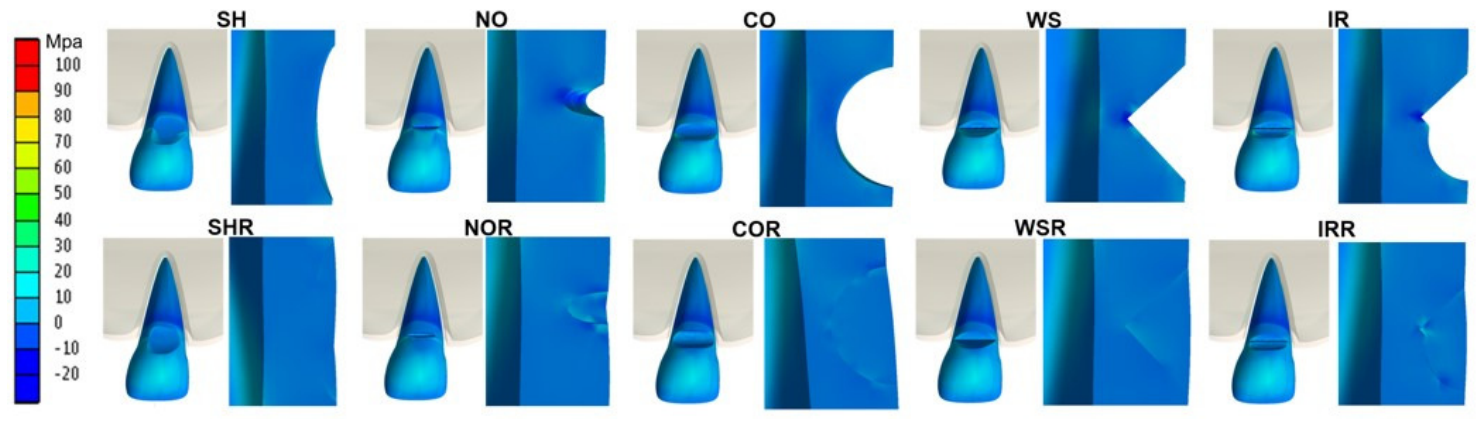

SHR

NOR
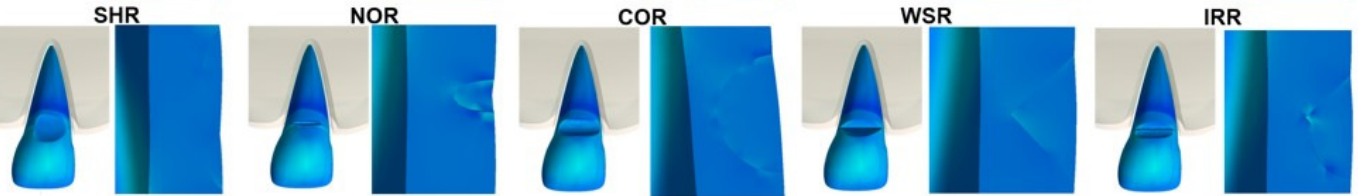

Figure 5. Maximum Principal Stress (MPa) distribution pattern for all NCCL morphologies and respective restored models submitted to ML. 

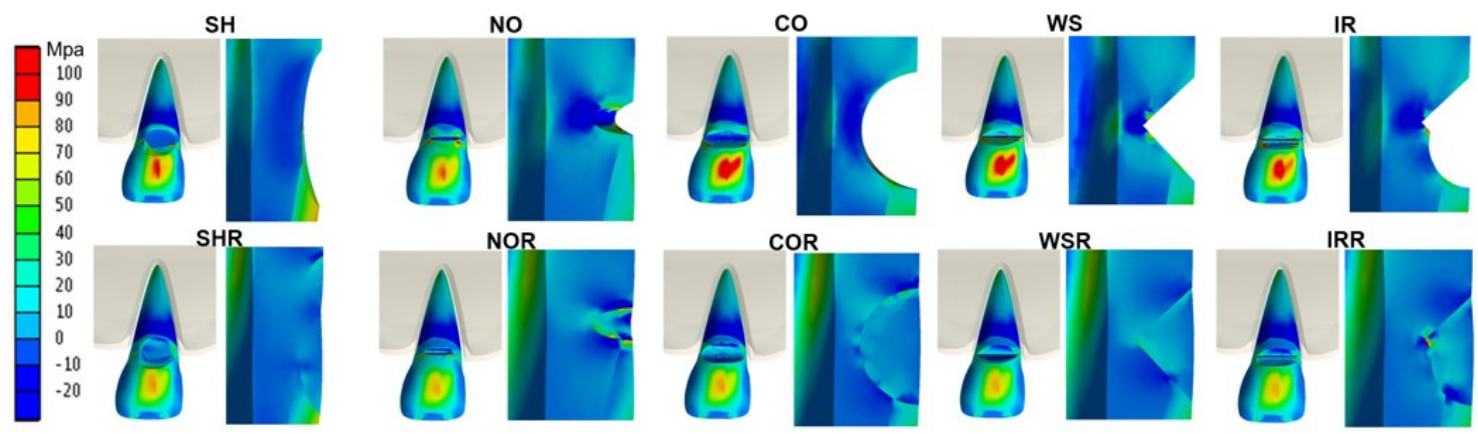

Figure 6. Maximum Principal Stress (MPa) distribution pattern for all NCCL morphologies and respective restored models submitted to IL.

The variation of load type propitiated pronounced differences in the stress distribution, regardless of the cervical wear, NCCLs morphology type and the presence of the restorative material (Fig. 4, 5 and 6). For all the models, IL was associated with more compressive stress concentration on bottom of the lesions than ML (Figs. 5 and 6). On SO, the compressive stress was lower for ML (-0.5 MPa) than IL (-4.8 MPa) (Fig. 4).

For ML, all morphologies promoted compressive stress in the bottom of the NCCL. However, the stress intensity was higher on acute angles morphologies and lesions with discrepant proportion between corono-apical height and mesiodistal length. Thus, WS (-14.9 MPa), IR" (-13.2 $\mathrm{MPa})$ and NO (-7.7 $\mathrm{MPa})$ presented the highest compression values. The type of stress pattern found on IL was similar to ML, however with higher magnitude. The NCCLs with rounded bottom, as $\mathrm{CO}$ (-13.4 MPa), IR' (-3.8 MPa) and SH (-2.8 MPa), showed lower values of compression stress, while WS (-136.3 MPa), IR" (-117.5 MPa) and NO (-71.1 $\mathrm{MPa}$ ) resulted in higher stress (Fig. 7). For both loads, SH showed lower stress values than the others morphology types, and a biomechanical behavior close to the SO.

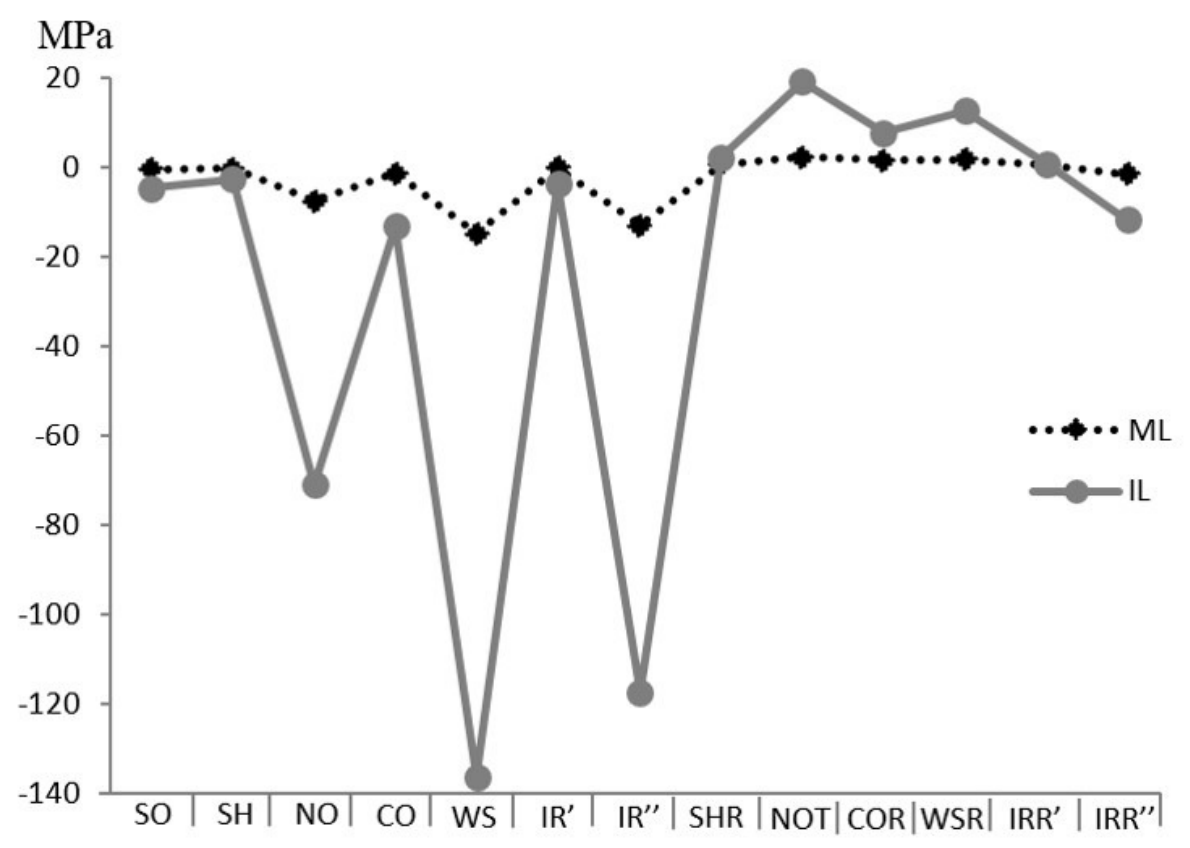

Figure 7. Maximum Principal Stress values (MPa) on the deeper node of NCCLs.

The simulated hybrid composite resin restoration promoted more harmonic biomechanical behavior for all morphologies, with stress distribution patterns similar to those found on SO, independent of load type (Figs. 5 and 6). However, the restored models presented higher stress magnitude on BL when submitted to ML, mainly for NOR (higher tensile stress: $2.1 \mathrm{MPa}$ ), and IRR" 
(higher compressive stress: -1.7 MPa). Similarly, for IL, the greater compressive stress was found on IRR" (-11.9 MPa), and the higher tensile stress was found on NOR (19.1 MPa) (Fig. 7).

The results of statistical comparisons are presented on tables 3 and 4 . The equivalent stress (von Mises) analysis before and after the NCCL restoration showed that the stress values obtained in the bottom of the lesion were lower in restored models, either for ML $(\mathrm{p}=0.001)$ or IL $(\mathrm{p}<0.001)$ (Table 3). In addition, a higher stress concentration was found for IL in non-restored NCCL $(p<0.001)$ and restored NCCL $(\mathrm{p}<0.001)$ when compared with the ML (Table 4).

Table 3. Mean Stress Values (MPa) and Standard Deviation (SD) comparing Non-restored NCCL x Restored NCCL.

\begin{tabular}{cccc}
\hline LOAD & NON-RESTORED NCCL & NCCL RESTORED & p VALUE \\
\hline MIDDLE THIRD & $40,916+-18,216$ & $9,301+-4,548$ & $0,002^{*}$ \\
INCISIAL THIRD & $377,737+-151,672$ & $83,225+-35,754$ & $<0,001^{*}$ \\
\hline
\end{tabular}

Table 4. Mean Stress Values (MPa) and Standard Deviation (SD) comparing Palatine Middle Third Load x Palatine Incisive Third Load.

\begin{tabular}{cccc}
\hline LOAD & MIDDLE THIRD & INCISAL THIRD & p VALUE \\
\hline NON-RESTORED NCCL & $40,916+-18,216$ & $377,737+-151,672$ & $<0,001^{*}$ \\
NCCL RESTORED & $9,301+-4,548$ & $83,225+-35,754$ & $<0,001^{*}$ \\
\hline
\end{tabular}

\section{DISCUSSION}

According to the results, the null hypothesis of this study was rejected. The load types, NCCL morphologies and restorative status promoted changes on the biomechanical behavior of maxillary incisor.

The loads applied simulated the magnitude and area of a standard force during the masticatory function on a sound maxillary central incisor (ML) and a parafunctional habits or non-physiological contact (IL) (POIATE et al., 2009; FRAGOSO et al., 2013). The IL presented higher stress concentration compared with ML for all the morphologies (Figs. 5 and 6). This fact is justified due to the greater load intensity and the higher strain promoted for IL. This load was applied more obliquely to the lesion than ML, promoting more flexion of the NCCL's walls (FRAGOSO et al., 2013). In addition, ML had a lower intensity and was applied near to cingulum region. This situation, favored more homogenous stress dissipation within the tooth structure, because the resultant force is parallel to the wall of the lesions.

For both load types, a tensile stress concentration was noted on the enamel at the center of the buccal face, due to the regions of load application and the higher elasticity modulus of the enamel. Considering a normal occlusion, the incisal edge of the lower incisors does not contact the palatine surface of the maxillary incisors, when the posterior teeth are occluded (KOHAUT, 2014). However, the palatine middle third load is considered physiological, due to the occurrence of anterior guidance movements during the chewing, to perform the seizure and cutting functions (POIATE et al., 2009; FRAGOSO et al., 2013; KOHAUT, 2014).

The morphologies with rounded bottom or similar proportion of corono-apical height and mesio-distal length (CO, IR' and $\mathrm{SH}$ ) demonstrated lower values of stress than the morphologies with well-defined internal angles or discrepant proportions (WS, IR" and NO). NCCLs which present well-defined internal angles, as WS and IR", had more stress concentration in the bottom of the lesion, because these short geometries promoted smaller area for stress dissipation (FRAGOSO et al., 2013). This fact was more apparent when these models where submitted to IL (Fig. 6). Although NO presented a rounded bottom and small geometry, the discrepant proportion between the short corono-apical height and longer mesio-distal length promote compressive stress concentration similarly to NCCLs with well-defined internal angles. This result contradict a previous study in which lesions with rounded angle presented lowest stress values at the bottom of the NCCL (FRAGOSO et al., 2013). For this reason, it would be more predictable classify NCCLs regarding the cavities dimension, rather than only by the geometry of the bottom.

The cervical area presents the enamel prisms and dentin tubules located transversely to the long axis of the tooth (HARIRI et al., 2012). This type of orientation associated with the dentin tubules higher density and volumes (HARRAN PONCE et al., 2001), result in less rigid and low 
strength enamel and dentin (AROLA e REPROGEL, 2006; MIURA et al., 2009; SOARES et al., 2010). In situations in which stress values are greater than the maximum tensile/compression of the hard tissue (DEJAK et al., 2005; BERNHARDT et al., 2006), micro cracks may occur and result in breaking of the bond between hydroxyapatite crystals (LEE e EAKLE, 1984). Thereby, due to the multifactorial etiology of the NCCLs (GRIPPO et al., 2012), high compressive and tensile stress values becomes the tooth structure more susceptible to dissolution by extrinsic and intrinsic acids and mechanical friction, and more vulnerable to NCCL progression (HUANG et al., 1992; GIANNINI et al., 2004; SOARES et al., 2010).

The NCCLs adhesive restorative procedure is recommended because it promotes a biomechanical behavior closer to the sound tooth (AW et al., 2002) and acts as an obstruction against biocorrosion and friction factors (MICHAEL et al., 2009). Moreover, the restorative material is considered an agent for obliterating the exposed dentinal tubules to hypersensitivity mechanism and meeting the aesthetic requirement (KIM et al., 2009; MICHAEL et al., 2009). Composite resin is commonly used to restore NCCLs (BURROW e TYAS, 2012), due to provide good clinical outcomes for longevity, aesthetics, adhesion and a harmonic biomechanical behavior for various types of cavities (SOARES, P. V., SANTOS-FILHO, P. C., QUEIROZ, E. C., et al., 2008; FERRACANE, 2011; STEWARDSON et al., 2012; FRAGOSO et al., 2013). On our findings, the reduction in the stress concentration in restored lesions provided some support for considered it as part of treatment, due to its elastic modulus similar to dentine is considered sufficient to offset the stress generated by non-physiologic occlusal forces (SENAWONGSE et al., 2010).

Despite SH showed homogenous stress pattern for both load types and presents a biomechanical behavior similar to the SO (being restored or not), the restorative procedure is recommended due to its ability to seal the dentin tubules and reduce the effects of chemical and friction factors on the dentin exposed. However, the NCCLs treatment is not simply substitute the dental structure or etiology removal due to its multifactorial etiology. The treatment successful depends on the patient monitoring in medium and long follow-up.

In attempt to minimize the stress concentration of certain NCCL's morphologies bottoms, to improve the bond strength values and decrease the failure rates, the literature suggests the rounding of internal angles, sclerotic dentin removal and even the creation of a retentive preparation before the restoration procedure (WOOD et al., 2008; KIM et al., 2009; ALLEGRI et al., 2010). Nevertheless, the current dentistry is undergoing a period which aims to be as more conservative as possible and preserve tooth structure. For this reason, according to the clinical success rates of NCCLs restored without preparation and the biomechanical behavior found in this study and other reaches from the literature, dentin wear prior the NCCLs restoration is not indicated (ICHIM et al., 2007; SANTOS et al., 2007; BURROW e TYAS, 2012; FRAGOSO et al., 2013; SOARES et al., 2015).

The finite element analysis measure stress distributions in teeth and restorations as a consequence to various loads, and it allows the responses of different dental tissues, taking account their biological properties (REES et al., 2003; SOARES, P. V., SANTOS-FILHO, P. C., GOMIDE, H. A., et al., 2008). One of the advantages of this method is the preservation of specimens, because it enables created 3D virtual models to test different load types, morphologies of NCCLs, and restorative status in the same model, preventing damages to the original specimens (REES et al., 2003; SOARES, C. J. et al., 2008). The 3D models allow simulate with more fidelity the anatomical dimensions and configuration of the tooth structure and the boundary conditions (POIATE et al., 2011), better than bi-dimensional (2D) models used in a previous study (FRAGOSO et al., 2013). 2D models overestimate the stress magnitude and do not represent the real model and its biomechanical behavior. Moreover, in this present study, enamel and dentin were considered orthotropic structures, with the same properties for transversal and $\mathrm{Z}$ axis, and different for longitudinal axis. This fact allowed simulates the lower rigidity of the cervical area due to the lower elastic modulus of dentin and enamel in this area (MIURA et al., 2009). In addition, since the simulation is not in identical FEA models, it enabled to perform statistical analysis with the equivalent stress values (Von Mises criterion) collected in BL. However, it should be noted that the role of stress in the etiology of NCCLs is still controversial and yet to be fully supported (KAIDONIS, 2008; NGUYEN et al., 2008; MICHAEL et al., 2009). Therefore, the mentioned theory would need to be supported by appropriately designed ex vivo laboratory and clinical studies of NCCL progression. This finite element study only demonstrated the major areas of 
high stress concentration and quantified the effect of morphology on this process.

\section{CONCLUSIONS}

The palatine contact on the incisal edge results in higher stress concentration compared with the physiological contact on the palatine middle third in maxillary incisors.

The NCCLs morphologies with welldefined internal angles or discrepant proportion between corono-apical height and mesio-distal length presented the highest values of compressive stress at the depth of the lesion.
The NCCLs restoration with adhesive material, such as hybrid composite resin promoted a biomechanical behavior more homogeneous and similar to sound teeth, independent of the internal angles geometry.

\section{ACKNOWLEDGMENTS}

This study was financed in part by the Coordenação de Aperfeiçoamento de Pessoal de Nível Superior - Brasil (CAPES) -Finance Code 001, CNPq and FAPEMIG. The authors report no conflicts of interest related to this study.

RESUMO: O objetivo deste estudo foi avaliar a influência de diferentes tipos de contatos anteriores e procedimentos restauradores na distribuição de tensões de incisivos superiores com diferentes morfologias de lesões cervicais não-cariosas (NCCLs). Modelos tridimensionais de um incisivo central superior foram gerados. Além do modelo hígido (SO), foram simuladas cinco morfologias de NCCLs: rasas (SH), entalhadas (NO), côncavas (CO), em forma de cunha (WS) e irregulares com centro duplo (IR' e IR'). Restauração com resina composta em todos os modelos foi simulada (R). Dois contatos anteriores diferentes foram aplicadas: $100 \mathrm{~N}$ no terço médio palatino (ML) e $500 \mathrm{~N}$ no terço incisal palatino (IL). Os dados foram obtidos em MPa utilizando os critérios de Tensão Máxima Principal e de Von Mises e a análise estatística foi realizada (teste t pareado com nível de significância de 95\%). A IL proporcionou maior estresse compressivo que ML, principalmente em WS (-136,3MPa), IR "(-117,5) e NO (-71,1 MPa). A maior tensão de tração encontrada nos modelos restaurados foi na NOR com IL (19,1 MPa). Os resultados de Von Mises mostraram maior concentração de estresse nos modelos não restaurados e IL $(p<0,001)$. O tipo de contato anterior e a presença de restauração foram fatores determinantes nas alterações do padrão de distribuição de estresse, enquanto as morfologias dos NCCLs tiveram pouca influência nos incisivos superiores.

PALAVRAS-CHAVES: Carregamento Anterior. Restauração em Resina Composta. Análise por Elementos Finitos. Incisivos superiores. Lesões Cervicais Não Cariosas.

\section{REFERENCES}

ALLEGRI, M. A.; LANDI, L.; ZUCCHELLI, G. Non-carious cervical lesions associated with multiple gingival recessions in the maxillary arch. A restorative-periodontal effort for esthetic success. A 12-month case report. Eur J Esthet Dent, v. 5, n. 1, p. 10-27, Spring 2010

AROLA, D. D.; REPROGEL, R. K. Tubule orientation and the fatigue strength of human dentin. Biomaterials, v. 27, n. 9, p. 2131-40, Mar 2006. https://doi.org/10.1016/j.biomaterials.2005.10.005

AW, T. C. et al. Characteristics of noncarious cervical lesions: a clinical investigation. J Am Dent Assoc, v. 133, n. 6, p. 725-33, Jun 2002. https://doi.org/10.14219/jada.archive.2002.0268

BERNHARDT, O. et al. Epidemiological evaluation of the multifactorial aetiology of abfractions. J Oral Rehabil, v. 33, n. 1, p. 17-25, Jan 2006. https://doi.org/10.1111/j.1365-2842.2006.01532.x

BORCIC, J. et al. The prevalence of non-carious cervical lesions in permanent dentition. J Oral Rehabil, v. 31, n. 2, p. 117-23, Feb 2004. https://doi.org/10.1046/j.0305-182X.2003.01223.x

BRANDINI, D. A. et al. Clinical evaluation of the association of noncarious cervical lesions, parafunctional habits, and TMD diagnosis. Quintessence Int, v. 43, n. 3, p. 255-62, Mar 2012. https://doi.org/10.1016/S00223913(12)60180-2 
BRANDINI, D. A. et al. Clinical evaluation of the association between noncarious cervical lesions and occlusal forces. J Prosthet Dent, v. 108, n. 5, p. 298-303, Nov 2012

BURROW, M. F.; TYAS, M. J. Comparison of two all-in-one adhesives bonded to non-carious cervical lesions--results at 3 years. Clin Oral Investig, v. 16, n. 4, p. 1089-94, Aug 2012. https://doi.org/10.1007/s00784-011-0595-y

CARTER, D. R.; HAYES, W. C. The compressive behavior of bone as a two-phase porous structure. J Bone Joint Surg Am, v. 59, n. 7, p. 954-62, Oct 1977. https://doi.org/10.2106/00004623-197759070-00021

DEJAK, B.; MLOTKOWSKI, A.; ROMANOWICZ, M. Finite element analysis of mechanism of cervical lesion formation in simulated molars during mastication and parafunction. J Prosthet Dent, v. 94, n. 6, p. 5209, Dec 2005. https://doi.org/10.1016/j.prosdent.2005.10.001

FERRACANE, J. L. Resin composite--state of the art. Dent Mater, v. 27, n. 1, p. 29-38, Jan 2011. https://doi.org/10.1016/j.dental.2010.10.020

FRAGOSO, Y. D. et al. The effects of long-term exposure to disease-modifying drugs during pregnancy in multiple sclerosis. Clin Neurol Neurosurg, v. 115, n. 2, p. 154-9, Feb 2013.

https://doi.org/10.1016/j.clineuro.2012.04.024

GIANNINI, M.; SOARES, C. J.; DE CARVALHO, R. M. Ultimate tensile strength of tooth structures. Dent Mater, v. 20, n. 4, p. 322-9, May 2004. https://doi.org/10.1016/S0109-5641(03)00110-6

GRIPPO, J. O.; SIMRING, M.; COLEMAN, T. A. Abfraction, abrasion, biocorrosion, and the enigma of noncarious cervical lesions: a 20-year perspective. J Esthet Restor Dent, v. 24, n. 1, p. 10-23, Feb 2012. https://doi.org/10.1111/j.1708-8240.2011.00487.x

GRIPPO, J. O.; SIMRING, M.; SCHREINER, S. Attrition, abrasion, corrosion and abfraction revisited: a new perspective on tooth surface lesions. J Am Dent Assoc, v. 135, n. 8, p. 1109-18; quiz 1163-5, Aug 2004. https://doi.org/10.14219/jada.archive.2004.0369

HARIRI, I. et al. Effects of structural orientation of enamel and dentine on light attenuation and local refractive index: an optical coherence tomography study. J Dent, v. 40, n. 5, p. 387-96, May 2012. https://doi.org/10.1016/j.jdent.2012.01.017

HARRAN PONCE, E.; CANALDA SAHLI, C.; VILAR FERNANDEZ, J. A. Study of dentinal tubule architecture of permanent upper premolars: evaluation by SEM. Aust Endod J, v. 27, n. 2, p. 66-72, Aug 2001. https://doi.org/10.1111/j.1747-4477.2001.tb00343.x

HUANG, T. J.; SCHILDER, H.; NATHANSON, D. Effects of moisture content and endodontic treatment on some mechanical properties of human dentin. J Endod, v. 18, n. 5, p. 209-15, May 1992.

https://doi.org/10.1016/S0099-2399(06)81262-8

HUR, B. et al. Characteristics of non-carious cervical lesions--an ex vivo study using micro computed tomography. J Oral Rehabil, v. 38, n. 6, p. 469-74, Jun 2011. https://doi.org/10.1111/j.1365-

2842.2010.02172.x

ICHIM, I. et al. Mechanical evaluation of cervical glass-ionomer restorations: 3D finite element study. J Dent, v. 35, n. 1, p. 28-35, Jan 2007. https://doi.org/10.1016/j.jdent.2006.04.003

KAIDONIS, J. A. Tooth wear: the view of the anthropologist. Clin Oral Investig, v. 12 Suppl 1, p. S21-6, Mar 2008. https://doi.org/10.1007/s00784-007-0154-8

https://doi.org/10.1007/s00784-007-0183-3 
KIM, S. Y. et al. Two-year clinical effectiveness of adhesives and retention form on resin composite restorations of non-carious cervical lesions. Oper Dent, v. 34, n. 5, p. 507-15, Sep-Oct 2009. https://doi.org/10.2341/08-006C

KOHAUT, J. C. Anterior guidance--movement and stability. Int Orthod, v. 12, n. 3, p. 281-90, Sep 2014. https://doi.org/10.1016/j.ortho.2014.06.010

https://doi.org/10.1016/j.ortho.2014.06.012

LAI, Z. Y. et al. Prevalence of non-carious cervical lesions and associated risk indicators in middle-aged and elderly populations in Southern China. Chin J Dent Res, v. 18, n. 1, p. 41-50, 2015.

LEE, W. C.; EAKLE, W. S. Possible role of tensile stress in the etiology of cervical erosive lesions of teeth. J Prosthet Dent, v. 52, n. 3, p. 374-80, Sep 1984. https://doi.org/10.1016/0022-3913(84)90448-7

MICHAEL, J. A.; KAIDONIS, J. A.; TOWNSEND, G. C. Non-carious cervical lesions on permanent anterior teeth: a new morphological classification. Aust Dent J, v. 55, n. 2, p. 134-7, Jun 2010.

https://doi.org/10.1111/j.1834-7819.2010.01228.x

MICHAEL, J. A. et al. Abfraction: separating fact from fiction. Aust Dent J, v. 54, n. 1, p. 2-8, Mar 2009. https://doi.org/10.1111/j.1834-7819.2008.01080.x

MIURA, J. et al. Multiscale analysis of stress distribution in teeth under applied forces. Dent Mater, v. 25, n. 1, p. 67-73, Jan 2009. https://doi.org/10.1016/j.dental.2008.04.015

NGUYEN, C. et al. A qualitative assessment of non-carious cervical lesions in extracted human teeth. Aust Dent J, v. 53, n. 1, p. 46-51, Mar 2008. https://doi.org/10.1111/j.1834-7819.2007.00009.x

OMMERBORN, M. A. et al. In vivo evaluation of noncarious cervical lesions in sleep bruxism subjects. J Prosthet Dent, v. 98, n. 2, p. 150-8, Aug 2007. https://doi.org/10.1016/S0022-3913(07)60048-1

PECIE, R. et al. Noncarious cervical lesions--a clinical concept based on the literature review. Part 1: prevention. Am J Dent, v. 24, n. 1, p. 49-56, Feb 2011.

POIATE, I. A. et al. Three-dimensional stress distribution in the human periodontal ligament in masticatory, parafunctional, and trauma loads: finite element analysis. J Periodontol, v. 80, n. 11, p. 1859-67, Nov 2009. https://doi.org/10.1902/jop.2009.090220

POIATE, I. A. et al. 2D and 3D finite element analysis of central incisor generated by computerized tomography. Comput Methods Programs Biomed, v. 104, n. 2, p. 292-9, Nov 2011. https://doi.org/10.1016/j.cmpb.2011.03.017

QUE, K. et al. A cross-sectional study: non-carious cervical lesions, cervical dentine hypersensitivity and related risk factors. J Oral Rehabil, v. 40, n. 1, p. 24-32, Jan 2013. https://doi.org/10.1111/j.13652842.2012.02342.x

REES, J. S.; HAMMADEH, M.; JAGGER, D. C. Abfraction lesion formation in maxillary incisors, canines and premolars: a finite element study. Eur J Oral Sci, v. 111, n. 2, p. 149-54, Apr 2003.

https://doi.org/10.1034/j.1600-0722.2003.00018.x

RUBIN, C. et al. Stress analysis of the human tooth using a three-dimensional finite element model. J Dent Res, v. 62, n. 2, p. 82-6, Feb 1983. https://doi.org/10.1177/00220345830620021701

SANTOS, V. R. et al. Effects of glass ionomer and microfilled composite subgingival restorations on periodontal tissue and subgingival biofilm: a 6-month evaluation. J Periodontol, v. 78, n. 8, p. 1522-8, Aug 2007. https://doi.org/10.1902/jop.2007.070032 
SENAWONGSE, P.; PONGPRUEKSA, P.; TAGAMI, J. The effect of the elastic modulus of low-viscosity resins on the microleakage of Class $\mathrm{V}$ resin composite restorations under occlusal loading. Dent Mater $\mathbf{J}, \mathrm{v}$. 29, n. 3, p. 324-9, May 2010. https://doi.org/10.4012/dmj.2009-086

SENNA, P.; DEL BEL CURY, A.; ROSING, C. Non-carious cervical lesions and occlusion: a systematic review of clinical studies. J Oral Rehabil, v. 39, n. 6, p. 450-62, Jun 2012. https://doi.org/10.1111/j.13652842.2012.02290.x

SHINYA, A. et al. Three-dimensional finite element analysis of metal and FRC adhesive fixed dental prostheses. J Adhes Dent, v. 10, n. 5, p. 365-71, Oct 2008.

SILVA, A. G. et al. The association between occlusal factors and noncarious cervical lesions: a systematic review. J Dent, v. 41, n. 1, p. 9-16, Jan 2013. https://doi.org/10.1016/j.jdent.2012.10.018

SOARES, C. J. et al. Effect of gamma irradiation on ultimate tensile strength of enamel and dentin. J Dent Res, v. 89, n. 2, p. 159-64, Feb 2010. https://doi.org/10.1177/0022034509351251

SOARES, C. J. et al. The influence of cavity design and glass fiber posts on biomechanical behavior of endodontically treated premolars. J Endod, v. 34, n. 8, p. 1015-9, Aug 2008.

https://doi.org/10.1016/j.joen.2008.05.017

SOARES, P. V. et al. Loading and composite restoration assessment of various non-carious cervical lesions morphologies - 3D finite element analysis. Aust Dent J, v. 60, n. 3, p. 309-16, Sep 2015.

https://doi.org/10.1111/adj.12233

SOARES, P. V. et al. Influence of restorative technique on the biomechanical behavior of endodontically treated maxillary premolars. Part II: strain measurement and stress distribution. J Prosthet Dent, v. 99, n. 2, p. 114-22, Feb 2008. https://doi.org/10.1016/S0022-3913(08)60027-X

SOARES, P. V. et al. Fracture resistance and stress distribution in endodontically treated maxillary premolars restored with composite resin. J Prosthodont, v. 17, n. 2, p. 114-9, Feb 2008. https://doi.org/10.1111/j.1532849X.2007.00258.x

STEWARDSON, D. et al. The survival of Class V restorations in general dental practice: part 3, five-year survival. Br Dent J, v. 212, n. 9, p. E14, May 2012. https://doi.org/10.1038/sj.bdj.2012.367

WALTER, C. et al. The anatomy of non-carious cervical lesions. Clin Oral Investig, v. 18, n. 1, p. 139-46, Jan 2014. https://doi.org/10.1007/s00784-013-0960-0

WEINSTEIN, A. M.; KLAWITTER, J. J.; COOK, S. D. Implant-bone interface characteristics of bioglass dental implants. J Biomed Mater Res, v. 14, n. 1, p. 23-9, Jan 1980. https://doi.org/10.1002/jbm.820140104

WOOD, I. et al. Non-carious cervical tooth surface loss: a literature review. J Dent, v. 36, n. 10, p. 759-66, Oct 2008. https://doi.org/10.1016/j.jdent.2008.06.004

WOOD, I. D.; KASSIR, A. S.; BRUNTON, P. A. Effect of lateral excursive movements on the progression of abfraction lesions. Oper Dent, v. 34, n. 3, p. 273-9, May-Jun 2009. https://doi.org/10.2341/08-100

ZEOLA, L. F. et al. Effects of non-carious cervical lesion size, occlusal loading and restoration on biomechanical behavior of premolar teeth. Aust Dent J, Dec 152015. 